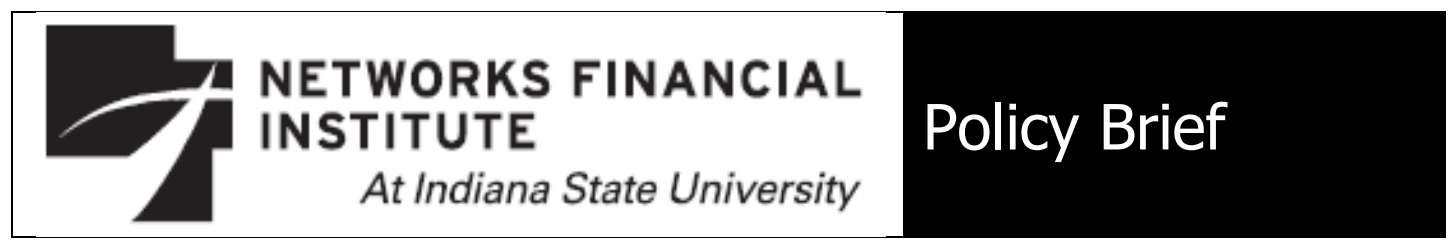

2010-PB-06

August 2010

\title{
Regulation of Bank Management Compensation David VanHoose
}

Abstract: Since passage of the Economic Stabilization Act of 2008, the government has been explicitly and implicitly regulating the compensation of top managers at a number of U.S. banks. In addition, bank regulators have added evaluations of bank management compensation packages to the list of factors taken into account in supervisory safety-andsoundness examinations, and pending legislation would require the Federal Reserve to establish explicit standards for evaluating the risk implications of bankers' pay.

Furthermore, the Federal Deposit Insurance Corporation has proposed incorporating the structure of bank management compensation into the determination of banks' deposit insurance premiums. This policy brief surveys the academic literature on the empirical relationship between bank management compensation and risk, discusses theoretical considerations that may underlie the mixed evidence regarding this relationship, and assesses potential pitfalls associated with actual and proposed regulations of the structure of management compensation in the banking industry. The main conclusion is that there is neither persuasive empirical evidence nor an unambiguous theoretical argument in favor of either direct or indirect regulation of bankers' pay.

About the Author: David VanHoose earned his Ph.D. at the University of North Carolina at Chapel Hill and is currently the Herman W. Lay Professor of Private Enterprise at teh Hankamer School of Business at Baylor University. Most recently, his work has appeared in Oxford Economic Papers, the Journal of International Money and Finance, and the European Journal of Political Economy. He has published articles in such professional journals as the Quarterly Journal of Economics, the International Economic Review, the Southern Economic Journal, the Journal of Money, Credit, and Banking, Economic Inquiry and the Scandinavian Journal of Economics. VanHoose served as a Visiting Economist at the Board of Governors of the Federal Reserve System in 1988 and as a Visiting Scholar at the Federal Reserve Bank of Kansas City in 1989. In 1991, he received the Iddo Sarnat Award for the outstanding article in the Journal of Banking and Finance, and in 1995 and 2000 he received the Atlantic Economic Journal's best article award. He is an editor of the Journal of Economics and Business and served on the editorial boards of Open Economies Review and the Atlantic Economic Journal. VanHoose is also the author of E-Commerce Economics, co-author (with Roger Leroy Miller) of Macroeconomics:Theories, Policies, and International Applications and Money, Banking and Financial Markets, and co-author of International Monetary and Financial Economics and Global Economic Issues and Policies.

Keywords: Bank management compensation, bank risk, deposit insurance.

JEL Classification: G28.

The views expressed are those of the individual author and do not necessarily reflect official positions of Networks Financial Institute. Please address questions regarding content to David VanHoose at

David_VanHoose@baylor.edu. Any errors or omissions are the responsibility of the author. NFI policy briefs and other publications are available on NFI's website (www.networksfinancialinstitute.org). Click "Thought Leadership" and then "Publications/Papers." 


\section{Regulation of Bank Management Compensation David VanHoose}

\section{Introduction}

The structure of management compensation influences agency problems involving both equity holders and debt holders. On the one hand, shareholders desire for managers to engage in actions that benefit the shareholders, which gives shareholders an incentive to tie managerial compensation to shareholder returns. On the other hand, tying management compensation to shareholder returns provides a potential mechanism for shareholders to shift risk to holders of the firm's debts. As documented by Demirgüç-Kunt et al. (2008), banking firms in most nations receive government-sponsored deposit insurance. Thus, among the potential debt holders on the receiving end of risk-shifting incentives potentially created by compensation arrangements aligning interests of bank managers with those of shareholders are the taxpayers who ultimately guarantee these deposit insurance systems.

Several actual and proposed regulations of bankers' pay have emerged in the aftermath of the recent panic and bailouts. Table 1 summarizes actual and proposed rules governing pay at U.S. banks. These include establishment of explicit pay ceilings for some institutions receiving "exceptional assistance" from the U.S. government, publication and distribution of new supervisory guidelines for bank compensation policies, incorporation of reviews of pay programs into supervisory examinations, and circulation of a proposal by the Federal Deposit Insurance Corporation (FDIC) to condition deposit insurance premiums on management compensation packages [see Adler (2010a, b)]. As discussed by Hill (2009), similar regulations and proposals have been advanced in other countries.

\section{Table 1}


Law/Rule/Proposal

\begin{tabular}{|c|c|}
\hline $\begin{array}{l}\text { Economic Stabilization Act of } \\
2008\end{array}$ & $\begin{array}{l}\text { - Sets a strict } \$ 500,000 \text { pay cap at institutions receiving } \\
\text { "exceptional assistance" } \\
\text { - Establishes a discretionary } \$ 500,000 \text { pay cap at } \\
\text { institutions receiving assistance under "generally } \\
\text { available capital access programs" }\end{array}$ \\
\hline $\begin{array}{l}\text { American Recovery and } \\
\text { Reinvestment Act of } 2009\end{array}$ & $\begin{array}{l}\text { - Limits bonus payments to no more than one-third of } \\
\text { total compensation } \\
\text { - Creates the office of Special Master of } \\
\text { Compensation—or "Pay Czar"- to oversee employee- } \\
\text { specific compensation decisions at } 7 \text { large institutions } \\
\text { receiving "exceptional assistance" and to establish pay } \\
\text { guidelines for institutions receiving assistance under } \\
\text { "generally available capital access programs" }\end{array}$ \\
\hline $\begin{array}{l}\text { Federal Reserve } \\
\text { "Guidance on Sound Incentive } \\
\text { Compensation Policies" } \\
\text { (October 22, 2009) }\end{array}$ & $\begin{array}{l}\text { - Requires reviews of incentive-compensation programs } \\
\text { to evaluate risk-taking incentives } \\
\text { - Subjects } 28 \text { specific large banks to detailed reviews of } \\
\text { systems for incentive compensation, risk management, } \\
\text { and corporate governance } \\
\text { - Adds reviews of incentive-compensation programs of } \\
\text { all banks to regular examinations and incorporates } \\
\text { results into supervisory ratings }\end{array}$ \\
\hline $\begin{array}{l}\text { Dodd-Frank Wall Street } \\
\text { Reform and Consumer } \\
\text { Protection Act (2010) }\end{array}$ & $\begin{array}{l}\text { Directs the Federal Reserve to establish formal } \\
\text { regulatory standards for pay practices } \\
\text { Rules must specify compensation practices that } \\
\text { contribute to unsafe and unsound banking }\end{array}$ \\
\hline $\begin{array}{l}\text { Federal Deposit Insurance } \\
\text { Corporation 12 CFR Part 327: } \\
\text { "Incorporating Employee } \\
\text { Compensation Criteria into the } \\
\text { Risk Assessment System" }\end{array}$ & $\begin{array}{l}\text { - Proposed adjustment of the FDIC's risk-rating system } \\
\text { to "adequately compensate" the Deposit Insurance } \\
\text { Fund for "the risks presented by certain compensation } \\
\text { programs" } \\
\text { - Proposal to set insurance premiums to provide } \\
\text { incentives to adopt compensation programs that "align } \\
\text { employees' interests with those of...other } \\
\text { stakeholders, including the FDIC" and "reward } \\
\text { employees for focusing on risk management" }\end{array}$ \\
\hline
\end{tabular}

\section{Form of Regulation}

Sources: Hill (2009), Mason (2009), FDIC (2010)

Some observers — for example, Macey and O'Hara (2003) — suggest that there is a strong justification for explicit involvement of policymakers in the establishment of rules governing internal management of banks. Others, such as Grant and Grant (2008), view the establishment of curbs on executive compensation 
to be in the interests of shareholders as well as taxpayers. Others, such as Mason (2009), contend that efforts to regulate bank management compensation are at best misguided and at worst counterproductive.

This policy brief provides an assessment of empirical and theoretical evaluations of the relationship between the structure of bank management compensation and bank risks and of possible effects of regulations. The following section surveys the current body of evidence regarding the relationship between the structure of bank management compensation and bank risks. Section 3 reviews theoretical rationales for regulation of bank management compensation. Section 4 evaluates the prospects for such regulatory policies to accomplish their intended objectives, both in light of available evidence and given the prevailing state of economic theory.

Section 5 provides a summary of the main conclusions.

\section{Evidence on the Relationship between Bank Management Compensation and Performance}

Before considering theoretical rationales for regulating bankers' pay, it is useful to review evidence in the academic literature. What does this literature suggest about the relationship between the structure of bank management compensation and bank performance?

Table 2 lists a number of key academic studies published during the past two decades, discusses the data upon which empirical analyses have based, and provides, and summarizes notable findings. Among these are performance based on stock returns and operating profits [Barro-Barro (1990)] and gains from actions such as mergers and acquisitions, with executives at larger banks receiving greater remuneration [Anderson et al. (2004)]; bank size [Barro-Barro (1990), Bliss-Rosen (2001)]; other manager characteristics, such as age and experience [Webb (2008)]; and features of corporate governance, with a lower degree of director independence 
being associated with higher management pay [Sierra et al. (2006), Cooper (2009)]. 
Table 2

Study

\begin{tabular}{|l|l|l|}
\hline Anderson-Becher-Campbell (2004) & $\begin{array}{l}\text { Sample of CEO compensation levels at } \\
\text { U.S. banks with billions of dollars of } \\
\text { assets that were involved in 97 mergers } \\
\text { during the 1990s }\end{array}$ & $\begin{array}{l}\text { There was a positive relationship } \\
\text { between changes in CEO compensation } \\
\text { and expected merger gains and actual } \\
\text { changes in operating profits. }\end{array}$ \\
\hline Barro-Barro (1990) & $\begin{array}{l}\text { Panel data for CEO compensation at 83 } \\
\text { large U.S. banks during the 1982-1987 } \\
\text { interval }\end{array}$ & $\begin{array}{l}\text { The value of the elasticity of } \\
\text { compensation with respect to assets was } \\
\text { about one-third for new CEOs; changes } \\
\text { in compensation reflected performance } \\
\text { as measured by stock and accounting } \\
\text { returns. }\end{array}$ \\
\hline Becher-Campbell-Frye (2005) & $\begin{array}{l}\text { Sample of 700 U.S. banks and more than } \\
13,000 \text { non-bank firms during the 1992- } \\
1999 \text { period }\end{array}$ & $\begin{array}{l}\text { Directors of U.S. banking firms received } \\
\text { less equity-based compensation than } \\
\text { directors of other firms, but a } \\
\text { consequence of banking deregulation } \\
\text { was increased use of equity-based } \\
\text { compensation with weak evidence of no } \\
\text { increase in risk. }\end{array}$ \\
\hline Bliss-Rosen (2001) & $\begin{array}{l}\text { Sergers had a positive effect on } \\
\text { companies that were among the 30 } \\
\text { largest in asset size in at least one year } \\
\text { and existed for at least five years within } \\
\text { the 1986-1995 sample period }\end{array}$ & $\begin{array}{l}\text { bank size on compensation; CEOs with } \\
\text { more stock-based compensation were } \\
\text { less likely to enter into a merger. }\end{array}$ \\
\hline
\end{tabular}

\section{Data Key Findings}

There was a positive relationship

compensation with respect to assets was bout one-third for new CEOs; changes

as measured by stock and accounting 
Table 2 (Continued)

\begin{tabular}{|l|l|l|}
\multicolumn{2}{|c}{ Study } & \multicolumn{2}{c}{ Data } \\
\hline Bolton-Mehran-Shapiro (2010) & $\begin{array}{l}\text { CEO deferred pay, pensions, and wealth } \\
\text { at 27 U.S. financial institutions since } \\
2007\end{array}$ & $\begin{array}{l}\text { Firms with larger shares of CEO deferred } \\
\text { compensation experience lower credit default } \\
\text { swap spreads, possibly indicating market } \\
\text { perceptions of lower risk. }\end{array}$ \\
\hline Chen-Steiner-Whyte (2006) & $\begin{array}{l}\text { CEO compensation and other data for 68 } \\
\text { U.S. banks and 70 CEOs during the } \\
1992-2000 \text { interval }\end{array}$ & $\begin{array}{l}\text { There was greater use of stock option-based } \\
\text { compensation for bank CEOs following } \\
\text { deregulation; various measures of risk } \\
\text { suggested that the result was increased } \\
\text { management risk taking. }\end{array}$ \\
\hline Chen-Steiner-Whyte (1998) & $\begin{array}{l}\text { Rolling samples of about 300 depository } \\
\text { institutions per year between 1988 and } \\
1993\end{array}$ & $\begin{array}{l}\text { There was a negative relationship between the } \\
\text { extent of managerial ownership and risk in } \\
\text { depository institution returns, particularly for } \\
\text { savings institutions. }\end{array}$ \\
\hline Čihák-Maechler-Schaeck-Stolz (2009) & $\begin{array}{l}\text { Banking executive (CEO, CFO, COO) } \\
\text { turnovers at U.S. banks over the 1990- } \\
\text { 2007 period }\end{array}$ & $\begin{array}{l}\text { Senior management dismissals were more } \\
\text { likely to occur at banks experiencing greater } \\
\text { risk, high losses, lower dividends, greater } \\
\text { charter value, and higher levels of subordinated } \\
\text { debt, with only limited evidence that forced } \\
\text { turnovers resulted in better performance. }\end{array}$ \\
\hline
\end{tabular}


Table 2 (Continued)

\begin{tabular}{|l|l|l|}
\multicolumn{2}{|l}{ Study } & Data \\
\hline Cooper (2009) & $\begin{array}{l}\text { Data on the composition of boards of } \\
\text { directors at 293 U.S. banks in 2006 }\end{array}$ & $\begin{array}{l}\text { An increased presence of management insiders } \\
\text { on bank boards of directors boosted both } \\
\text { director and executive compensation; directors } \\
\text { were awarded for high ratings from regulators }\end{array}$ \\
\hline Crawford-Ezzell-Miles (1995) & $\begin{array}{l}\text { Data on compensation of 239 CEOs at } \\
124 \text { U.S. banks over the 1976-1988 } \\
\text { period }\end{array}$ & $\begin{array}{l}\text { Greater pay-performance sensitivity existed in } \\
\text { the 1982-1988 subsample than in the pre- } \\
\text { deregulation 1976-1981 subsample, } \\
\text { particularly at low-capitalized banks. }\end{array}$ \\
\hline Gropp-Köhler (2010) & $\begin{array}{l}\text { Data from 2007 and 2008 for 1,142 } \\
\text { banks with more than \$1 billion in assets } \\
\text { located in 25 OECD countries }\end{array}$ & $\begin{array}{l}\text { Shareholder-controlled banks took on more } \\
\text { risk and obtained more government assistance } \\
\text { than manager-controlled banks. }\end{array}$ \\
\hline Hagendorff-Vallascas (2010) & $\begin{array}{l}\text { Data on relationships between CEO } \\
\text { wealth and pay-performance sensitivities } \\
\text { inferred from 1,462 bank merger deals } \\
\text { between 1993 and 2008 }\end{array}$ & $\begin{array}{l}\text { Limited evidence that greater pay-performance } \\
\text { sensitivity reduces risk-taking mergers and } \\
\text { evidence that CEOs at larger banks engage in } \\
\text { riskier mergers. }\end{array}$ \\
\hline Harjoto-Mullineaux (2003) & $\begin{array}{l}\text { CEO compensation at } 84 \text { U.S. bank } \\
\text { holding companies between 1992 and } \\
\text { 2000 }\end{array}$ & $\begin{array}{l}\text { There was an increased link between growth } \\
\text { options and CEO compensation in the 1990s; } \\
\text { greater pay-performance sensitivities at bank } \\
\text { holding companies involved in securities } \\
\text { underwriting; reduced pay-performance } \\
\text { sensitivities as variability of returns increases. }\end{array}$ \\
\hline
\end{tabular}


Table 2 (Continued)

\begin{tabular}{|l|l|l|}
\multicolumn{2}{|c}{ Study } & \multicolumn{1}{c}{ Kata } \\
\hline Houston-James (1995) & $\begin{array}{l}\text { Data on CEO compensation for 134 of the } \\
\text { largest U.S. commercial banks between } \\
1980 \text { and } 1990\end{array}$ & $\begin{array}{l}\text { There was a strong positive relationship } \\
\text { between equity-based incentives and bank } \\
\text { charter value; there was no evidence that } \\
\text { CEO compensation policies promoted } \\
\text { excessive risk taking during the interval } \\
\text { studied }\end{array}$ \\
\hline Hubbard-Palia (1995) & $\begin{array}{l}\text { CEO compensation at 147 U.S. banks } \\
\text { during the 1980-1989 interval }\end{array}$ & $\begin{array}{l}\text { Stronger pay-performance sensitivities } \\
\text { were higher in interstate banking markets; } \\
\text { CEO turnover increased substantially after } \\
\text { deregulation. }\end{array}$ \\
\hline John-Mehran-Qian (2010) & $\begin{array}{l}\text { Data on CEO compensation at 143 U.S. } \\
\text { bank holding companies and 997 } \\
\text { manufacturing firms during the 1993-2007 } \\
\text { period }\end{array}$ & $\begin{array}{l}\text { Consistent with the idea that pay- } \\
\text { performance sensitivities respond to risk- } \\
\text { shifting incentives, these sensitivities were } \\
\text { declining in the bank's leverage ratio and } \\
\text { increasing in the intensity of outside } \\
\text { monitoring by holders of subordinated } \\
\text { debts and regulators. }\end{array}$ \\
\hline John-Qian (2003) & $\begin{array}{l}\text { Bank pay-performance sensitivity } \\
\text { decreased with higher leverage ratios and } \\
\text { greater bank size; bank pay-performance } \\
\text { sensitivity was lower than at } \\
\text { manufacturing firms. }\end{array}$ \\
\hline
\end{tabular}


Table 2 (Continued)

\begin{tabular}{|l|l|l|}
\hline \multicolumn{2}{|c}{ Study } & \multicolumn{1}{c}{ Data } \\
\hline Laeven-Levine (2009) & $\begin{array}{l}\text { Data on ownership structures of up to 279 } \\
\text { large banks across 48 nations as of the end } \\
\text { of 2001 }\end{array}$ & $\begin{array}{l}\text { Greater cash-flow rights by larger equity } \\
\text { owners are associated with increased bank } \\
\text { risk; an increased share of equity rights } \\
\text { also is associated risk rising in response to } \\
\text { tougher regulation and more access to } \\
\text { deposit insurance }\end{array}$ \\
\hline Minnick-Unal-Yang (2009) & $\begin{array}{l}\text { Compensation to CEOs involved in 178 } \\
\text { acquisitions by 65 U.S. bank holding } \\
\text { companies between 1991 and 2005 }\end{array}$ & $\begin{array}{l}\text { CEOs with compensation exhibiting } \\
\text { greater pay-performance sensitivity were } \\
\text { less likely to engage in value-reducing } \\
\text { mergers. }\end{array}$ \\
\hline Palia-Porter (2004) & $\begin{array}{l}\text { 1991 CEO compensation data for 102 U.S. } \\
\text { bank holding companies }\end{array}$ & $\begin{array}{l}\text { Increases in the salary and bonus } \\
\text { components of bank management and } \\
\text { compensation packages were associated } \\
\text { with lower risk. }\end{array}$ \\
\hline Saunders-Strock-Travlos (1990) & $\begin{array}{l}\text { Data on the composition of shareholders at } \\
38 \text { U.S. bank holding companies between } \\
1978 \text { and 1985 }\end{array}$ & $\begin{array}{l}\text { Predominantly stockholder-controlled } \\
\text { banks exhibited greater risk-taking } \\
\text { behavior than predominantly managerially- } \\
\text { controlled banks as a consequence of } \\
\text { deregulation. }\end{array}$ \\
\hline
\end{tabular}




\section{Table 2 (Continued)}

$\underline{\text { Study }}$

\begin{tabular}{|l|l|}
\hline Sierra-Talmor-Wallace (2006) & $\begin{array}{l}\text { Compensation data for CEOs of 76 U.S. } \\
\text { bank holding companies during the 1992- } \\
1997 \text { period }\end{array}$ \\
\hline Webb (2008) & $\begin{array}{l}\text { Compensation paid to top executives at } \\
\text { 107 U.S. banks during the 1992-2004 } \\
\text { interval }\end{array}$ \\
\hline Westman (2010) & $\begin{array}{l}\text { A sample of 995 bank-year observations } \\
\text { from 548 banks in 37 European nations }\end{array}$ \\
& $\begin{array}{l}\text { Data on stock option compensation paid to } \\
\text { CEOs involved in 131 U.S. bank mergers } \\
\text { between } 1993 \text { and } 2002\end{array}$ \\
\hline Williams-Michael-Rao (2008) & \\
\hline
\end{tabular}

\section{Key Findings}

Greater independence of a bank's board of directors from management was associated with stronger performance, lower levels of executive pay, and smaller rates of growth of executive pay.

Pay-performance sensitivity was weakly affected by regulatory monitoring but varies inversely with the age of bank CEOs.

The extent of bank risk taking increases with a greater degree of interaction between concentration of bank equity ownership and greater availability of particularly generous deposit insurance programs.

The use of stock options within bank CEO compensation packages was associated with a higher post-merger level of equity risk. 
The studies indicate that the sensitivity of compensation to performance in the banking industry has tended to lag behind the pay-for-performance sensitivity observed in other industries [Becher et al. (2005), Crawford et al. (1995), John-Qian (2003)]. Various factors have influenced the degree of sensitivity of bank manager compensation to observed performance. Several studies find evidence that the payperformance sensitivity increased during periods of banking deregulation and widespread merger activity [Houston-James (1995)]. To some extent, the resulting increase in average bank size with the advent of interstate banking contributed to the higher pay-performance sensitivity [Chen et al. (2006), Hubbard-Palia (1995)]. Nevertheless, a broadening in the range of business lines also clearly played a role in leading to management compensation becoming more sensitive to performance [Harjoto-Mullineaux (2003)].

Research clearly indicates that the primary means through which bank managers' pay became more sensitive to the performances of their institutions was via the use of equity-based incentives such as stock options. Some work indicates that pay-performance sensitivities generated by use of equity-based mechanisms tend to be higher for banks with lower ratios of debt to equity and in the presence of more intensive monitoring by debt holders and regulators [John et al. (2010) and John-Qian (2003)]. The ultimate pay-for-performance actions-dismissals of management - occur for reasons that are not too surprising, including poor performance and increased indebtedness [Čihák et al. (2009)] and weak performances in deregulated and hence more competitive markets [Hubbard-Palia (1995)].

From a regulatory standpoint, a fundamental issue is the relationship between bank management compensation and risk. Some studies find no evidence that greater pay-performance sensitivities are associated with increased risk taking [Becher et al. (2005), Houston-James (1995)]. One study suggests that increasing 
the share of management compensation derived from salary and bonuses contributes to reduced bank risk [Palia-Porter (2004)]. Other research concludes that linking bank executives' pay to equities' values makes it more likely that they will take adverse actions such as potentially value-reducing mergers [Williams-Michael-Rao (2008)] or generally engage in greater risk taking [Chen et al. (2006)]. Others reach contrary conclusions on whether greater pay-performance sensitivity increases the risk of value-reducing mergers [Bliss-Rosen (2001), Minnick et al. (2009), and Hagendorff-Vallascas (2010)]. In addition, there is a finding of a negative relationship between greater pay-performance sensitivity and variability of returns [Harjoto-Mullineaux (2003)]. There is also evidence that risk-taking behavior depends on the degree of management control generally exercised by equity holders [Saunders et al. (1990) and Gropp-Köhler (2010)] and by a few large equity holders [Laeven-Levine (2009) and Westman (2010)] and on whether management compensation is deferred [Bolton et al. (2010)].

On net, the empirical literature indicates an increased dependence of bank management compensation on equity returns since the movement toward banking deregulation began in the 1980s. The literature yields more mixed conclusions, however, about whether this shift contributed to greater bank management risktaking behavior. The academic literature's net conclusion is that the relationship between the structure of bank executive pay packages and management risk taking ultimately hinges on various other factors that differ across countries and that likely differ across individual institutions within any given nation [see Craig (2004) for a similar judgment]. 


\section{Bank Management Compensation, Risk, and Regulation: Theory}

There have been a limited number of theoretical analyses of the relationship among bank management compensation, risk, and a possible role for regulation. As discussed by Kay and Van Putten (2007), during the 1990s and early 2000s, companies made greater use of options in management compensation packages, and some of the studies listed in Table 2 document the utilization of options in bank manager contracts. Does incorporating options payments into compensation arrangements tend to make managers more or less averse to risk? The work of Ross (2004), which focuses on the general question of how payment of options to agents affects their risk aversion, suggests that the answer to this question is theoretically ambiguous. Ross finds that an options-based compensation package aimed at inducing an agent to operate along the risk-averse portion of the agent's preference function will, other things being equal, tend to achieve this aim. The difficulty is that other things are not equal, both because of slippage in the linkage from compensation to preferences and because of wealth effects caused by the ways in which compensation can enlarge or contract the magnitude of a marginal gamble on risk. Consequently, Ross concludes that the risk effects of options-based compensation packages cannot readily be determined from a purely theoretical perspective.

To examine the nature of the tension between the interests of holders of equity and debts in a more narrow setting relating to the structure of bank management compensation, Schreiber (1997) considers a framework in which equity holders and managers each hold call options on portions of the distribution of the value of a bank's risky assets net of the value of its liabilities over states of the world in which their net value is positive. A deposit insurer writes a call option on the portion corresponding to states in which the net value of assets in relation to liabilities is negative. 
Schreiber studies settings in which the bank insurer is or is not aware of the bank's risk level when setting the bank's deposit insurance premium. In addition, a bank manager's salary is either predetermined or supplemented by a bonus conditioned on the bank's assets. When the deposit insurer knows the bank's risk level in advance of determining the deposit insurance premium, the setting of an actuarially fair premium that results means that the gross amount of funds available to be split between owners and the manager (whether or not a bonus is included) will be fixed and unrelated to risk. Owners will tend to prefer greater risk that pushes up the value of equity in good states of the world while transferring a large portion of risk to the deposit insurer in bad states, while the manager will prefer less risk. When the deposit insurer is unaware of the bank's overall risk prior to determining the insurance premium, however, the level of the premium will not be at the actuarially fair value, so the total pool of funds that will be available for splitting between owners and the manager will vary with risk.

Schreiber conducts simulations indicating, under this form of informational asymmetry, that a manager receiving a fixed salary prefers more risk in order to generate a higher salary up to a certain point, beyond which greater risk is less preferred by the manager. When the manager receives a bonus in this asymmetricinformation situation, however, the manager's attitude toward risk matches the attitude of owners, resulting in a preference for more risk on the part of the manager.

In Schreiber's analysis, deposit insurance premiums are contingent on a bank's risk level but are not directly linked to the structure of the bank's management compensation package. The theoretical analysis provided by John et al. (2000) suggests a motivation for a deposit insurer and regulator to explicitly tie deposit insurance premiums to the bank's management compensation structure. John et al. consider a setting in which a bank with fixed equity $(E)$ initially issues a 
fixed amount of deposits $(D)$. Prior to allocating these funds to its asset portfolio, the bank pays a deposit rate premium $\pi$ to a government agency that seeks to raise sufficient funds, on average, to protect the bank's depositors against realized outcomes in which the bank cannot honor payment guarantees to depositors. In advance of the bank's asset allocation choice, all banks contracts are written and priced in the market, so the deposit rate and the price of the bank's equity are determined.

To contemplate the bank's asset decision within the John et al. framework, let's consider a diagrammatic representation of their analysis. In Figure 1, the bank can choose between either a risky asset that yields either a high $(H)$ value or a low $(L)$ value, or a "safe" asset that offers zero risk but yields a return with nonnegative net present value between $H$ and $L$. There is a fixed probability of obtaining the high return $H$ on the risky asset, with one less this probability being the probability of realizing the lower return $L$, and this probability is uniformly distributed between 0 and 1 . The bank can also allocate its assets to combinations of the safe and risky assets, resulting in a continuum of feasible investment policies for the bank along the interval between 0 and 1 along the horizontal axes in the figure. Panel (a), which is drawn under the assumption that the certain return on the safe asset is less than the average return on the risky asset, depicts ranges of resulting expected values of the bank's end-of-period cash flows associated with alternative investment policies. Investment policy 1 corresponds to holding all safe assets, which yields the certain terminal cash flow $\bar{V}$, while investment policy 0 is associated with holding all risky assets. 


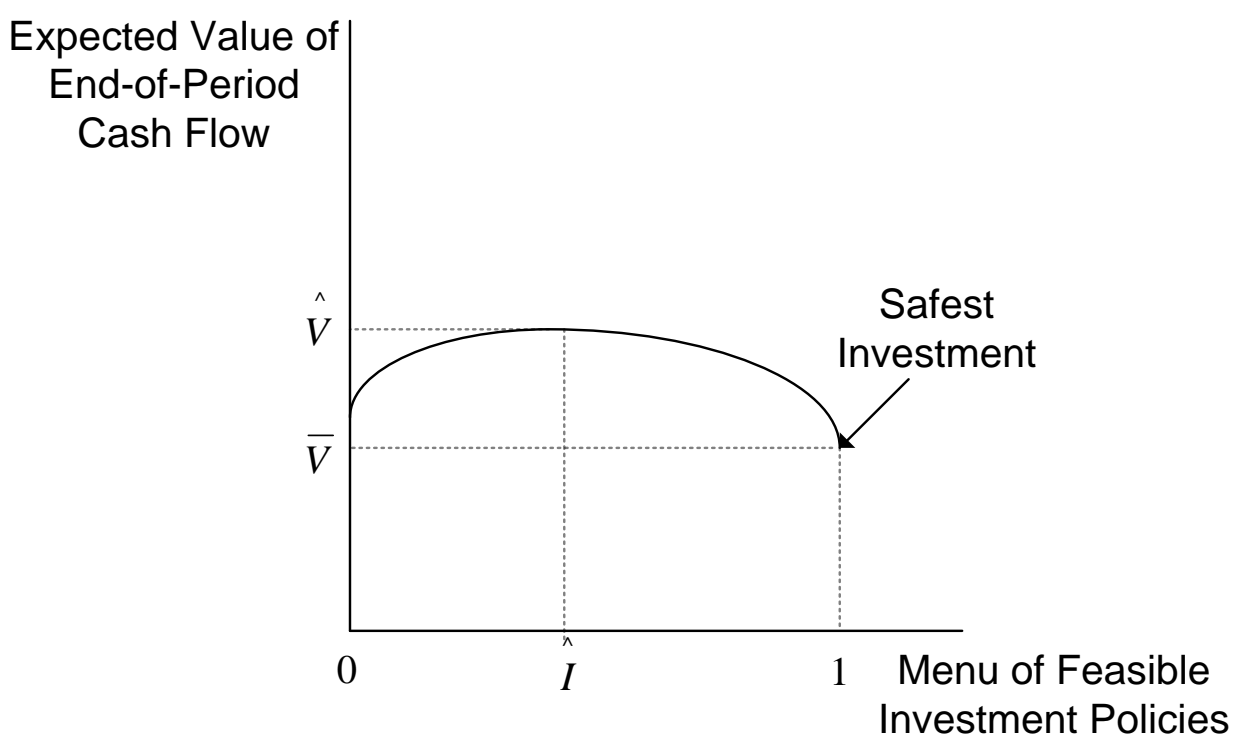

(a)

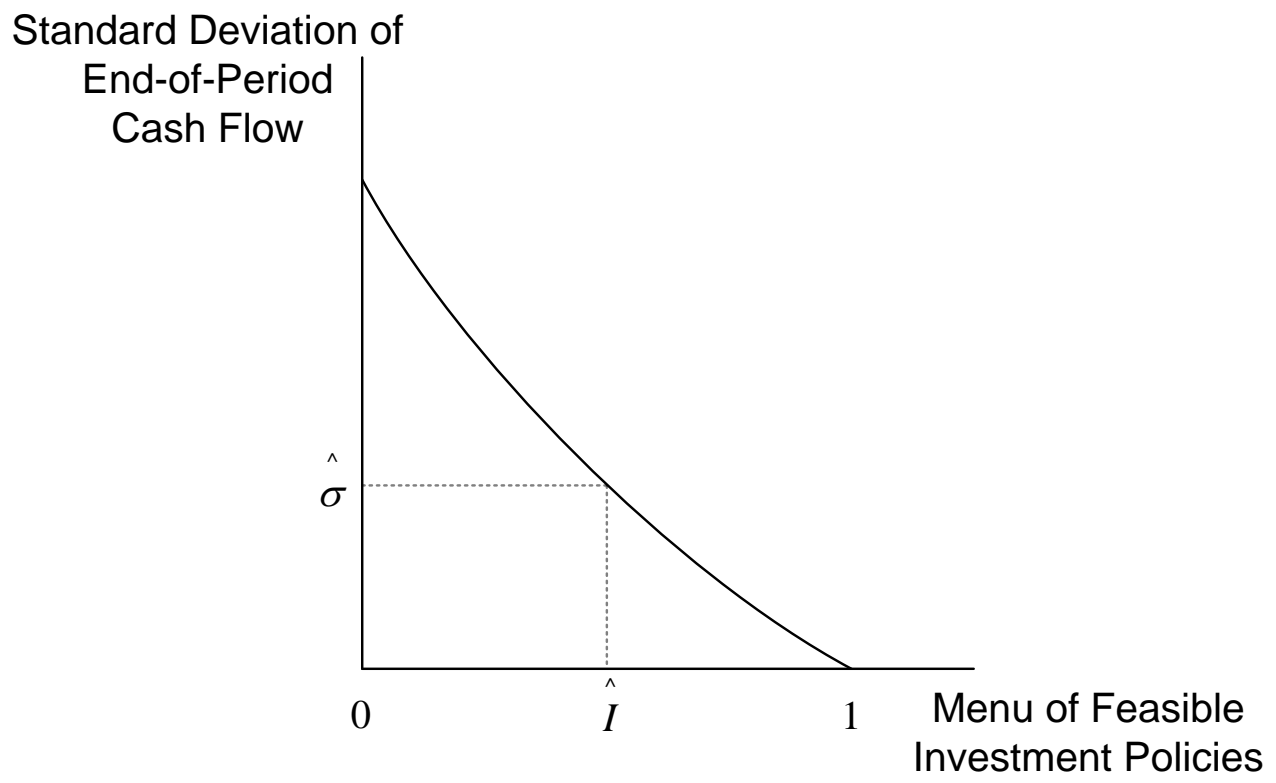

(b)

Figure 1 
Panel (b) of Figure 1 depicts the standard deviations corresponding to the alternative investment policies, with bank investment policy 1 yielding a standard deviation of terminal cash flows equal to zero and investment policy 0 yielding the highest standard deviation among feasible investment policies.

John et al. assume that the bank's objective is to maximize the expected value of its end-of-period cash flows. In panel (a) of Figure 1, the mix of safe and risky assets associated with attaining this objective is denoted as investment policy $I$. Given the assumption that a uniform distribution governs the return on the risky investment, this optimal investment policy corresponds to the probability associated with receiving the high return on the risky asset. The investment policy $I$ yields the highest feasible expected terminal cash flow $V$ given the bank's asset mix. In panel (b), the resulting standard deviation of the bank's end-of-period cash flow is denoted $\hat{\sigma}$.

John et al. also assume that at the end of the period, the bank must make a promised fixed payment $F$ to its depositors-presumably equal to $D$ plus interest payments at the market rate of interest - and that the value of $F$ exceeds the value of L. This means that if the bank holds a sufficiently large mix of its asset portfolio as risky assets, there is the potential for the expected value of its end-of-period cash flow to be less than what the bank owed depositors. Thus, the bank potentially can fail. To protect against this possibility, the deposit insurer would have to set the deposit insurance premium at an actuarially fair value, $\hat{\pi}$, that would cover expected losses to the bank given the investment policy $\hat{I}$.

John et al. consider a situation in which the bank possesses inside information about the probability governing the return on the risky asset. To simplify, they assume that the bank's managers can select this probability - that is, select a particular risky asset possessing this probability - contingent on other information available to them. To contemplate the complications this possibility 
raises, suppose that Figure 1 applies to a setting in which the bank possesses no inside information, so that the probability governing the returns on the risky assets is known to everyone. Consequently, the investment policy $\hat{I}$ displayed in Figure 1 and the resulting expected value of and standard deviation of the terminal cash flows given by $\hat{V}$ and $\hat{\sigma}$ can be viewed as benchmarks for evaluating the implications of possession of inside information by the bank.

Figure 2 explains the implications of inside information and evaluates the implications of bank capital regulation and fair-value deposit insurance pricing in John et al.'s model. The bank's managers select an investment policy in light of the known payment obligation to deposits. This investment policy is given by $I(F)$ in Figure 2. Because $I(F)<\hat{I}$, the bank's managers select riskier assets - that is, assets with a lower probability of yielding the high return $H$ and hence a higher probability of yielding the low return $L$. The bank's managers do so because this choice yields a higher expected residual payoff_-over and above the amount $F$ owed to depositors out of the bank's overall expected end-of-period cash flow-to holders of the bank's equity. 


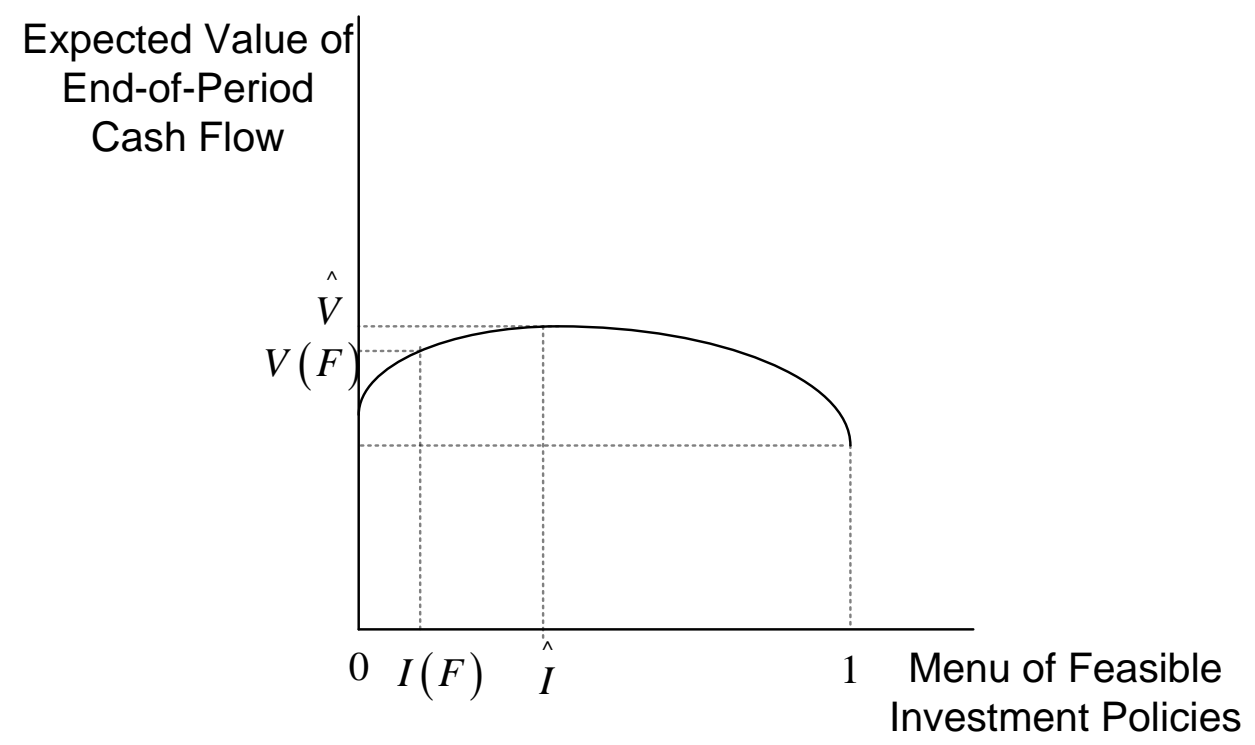

(a)

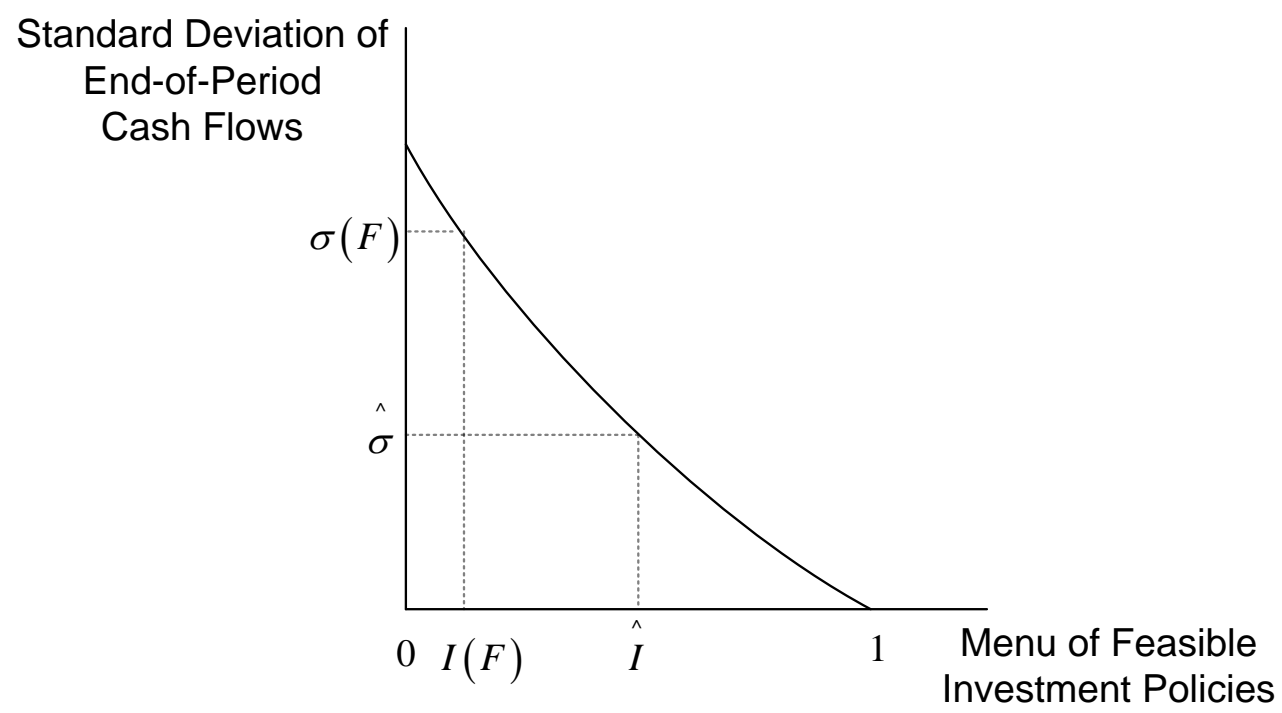

(b)

Figure 2 
The expected end-of-period cash flow when the bank's managers have inside information is $V(F)$, which as shown in panel (a) of Figure 2 is less than $\hat{V}$, and standard deviation of the bank's end-of-period cash flow is $\sigma(F)$, which as shown in panel (b) is smaller than $\sigma$. Thus, the simultaneous presence of deposit insurance and inside information on the part of the bank's managers induces the managers to opt for a riskier asset mix in pursuit of higher potential returns for shareholders facing the outside debt to depositors $F$. Deposit insurance, therefore, creates a moral hazard problem - an incentive for the bank's managers possessing inside information about the distribution of asset risks to choose a riskier portfolio and to shift the higher risks to the deposit insurer.

John et al. point out that one way to try to partially offset this risk-shifting incentive of deposit insurance is to engage in capital regulation. In their model, with the overall size of the bank's liabilities fixed at $D+E$, ex ante, this can be done by requiring a higher value of $E$, thereby reducing $D$ and hence the contracted value of $F$. The effect of an exogenous reduction in $F$, they demonstrate, would be to raise the value of $I(F)$ in Figure 2, thereby boosting the expected value of the bank's terminal cash flow closer to $V$ and reducing the standard deviation nearer to ^ $\sigma$.

With such a capital requirement in force, John et al. demonstrate, an actuarially fair deposit insurance premium covering the expected deposit insurance payout, given the riskier investment policy $I(F)$, can be calculated. Nevertheless, the premium rate is calculated given this risk-shifting investment policy - and hence is a function of $F$, or $\pi(F)$. The setting of this actuarially fair premium does nothing, therefore, to offset the moral hazard problem of deposit insurance, so it will still be the case that $V(F)<\hat{V}$ and that $\sigma(F)>\hat{\sigma}$. Bank equity owners will still prefer the risk-shifting investment policy $I(F)$ that yields these outcomes, and as long as the bank managers' incentives are aligned with those of the equity owners, 
the managers will deliver this policy.

To induce bank managers to opt for the investment policy $\hat{I}$ - that is, to induce bank managers to select the same asset allocation they would make if they did not possess inside information—John et al. propose relating the deposit insurance premium charged to the bank to the structure of compensation paid to its managers. They consider management compensation structure depicted in Figure 3. Up to the point at which the bank's end-of-period cash flow is less than the fixed payment $F$ due depositors, the bank's managers receive a fixed salary, $S$. As remuneration for generating a cash flow sufficiently high to cover $F$, the managers can earn a bonus as high as the value $B$. If the terminal cash flow exceeds the sum of the salary and the bonus, $S+B$, then the managers receive a fraction $e$ of the resulting addition to stockholders' equity.

Under John et al.'s proposed deposit insurance policy, the premium rate selected by the deposit insurer is set with an aim to inducing the bank's equity owners to select a combination of contract terms involving $S, B$, and $e$ consistent with management replication of the investment policy $\hat{I}$. In the context of their specific framework, John et al. calculate that a bank management compensation structure consistent with this outcome satisfies the condition $\hat{B}=\frac{\hat{e}}{(1-\hat{e})}(F-L)$. This condition implies that larger shares of additional returns to equity holders generated by terminal cash values over and above the fixed payment to depositors and fixed manager bonus should accompany a value of a higher manager bonus. Suppose that the condition above is satisfied and then the bonus is decreased to a value, $\hat{B^{\prime}}$, while $\hat{e}$ is held unchanged. Then the bonus is "too low," which gives the manager an incentive to opt for a riskier investment policy; reducing $e$ to a smaller value thereby will realign the manager toward a less risky investment policy 
that is more likely to ensure a terminal cash flow sufficient to cover both the depositor payment and the smaller bonus.

$$
\text { A diagrammatic depiction of the condition } \hat{B}=\frac{\hat{e}}{(1-\hat{e})}(F-L) \text { for }
$$
generating management replication of the investment policy $I$ is displayed in Figure 4. The figure also depicts a specific point along this locus of $\hat{B}-\hat{e}$ combinations in which $e$ is set equal to $1 \frac{1}{2}$, so that equity owners grant managers a 50 percent share of their gross equity return. This compensation arrangement aligns the managers' incentives closely with their own preferences. In this case, $\frac{e}{(1-\hat{e})}=1$, so the condition requires that the bonus be set at the value $\hat{B}=F-L$. Thus, if the bank's assets yield the low return $L$, the bank's managers have an incentive to generate a sufficient terminal cash flow to pay off depositors and cover their own bonus payment before generating additional returns for equity holders. 


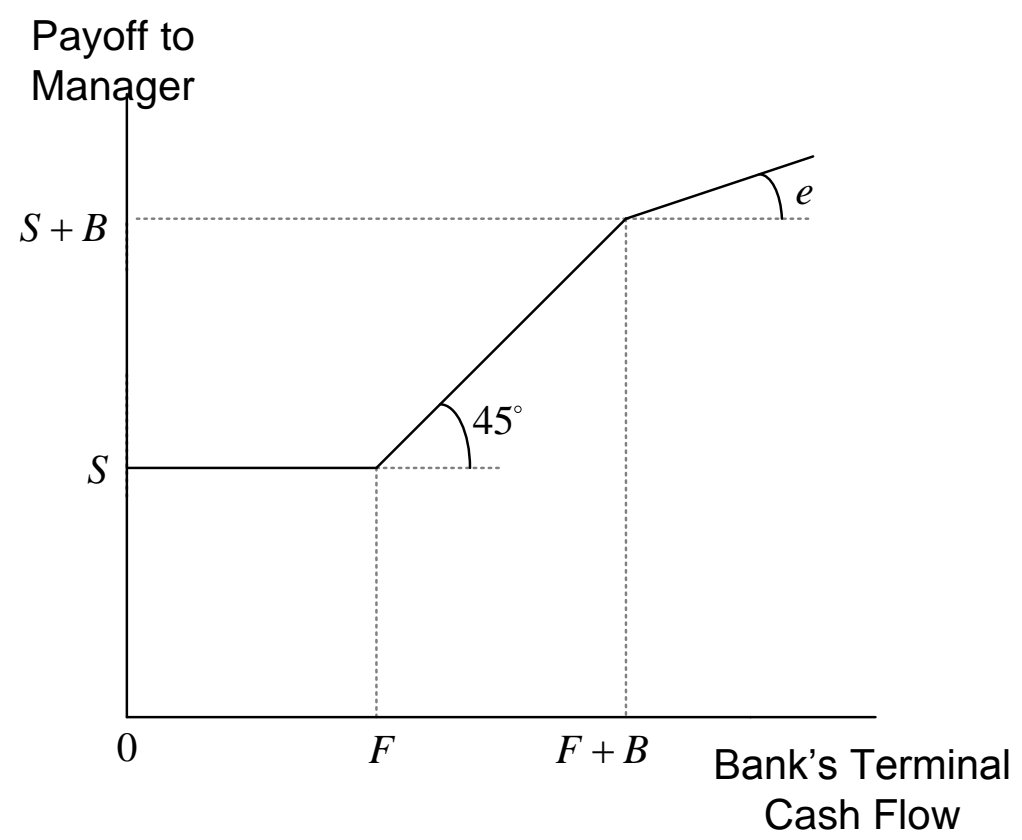

Figure 3

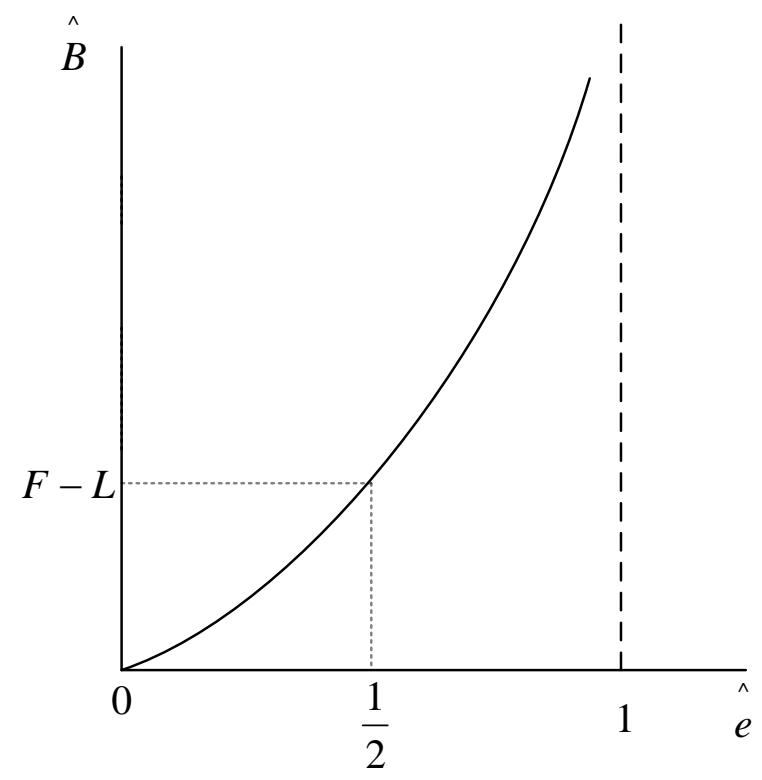

Figure 4 
Interestingly, John et al.'s compensation arrangement is comparable to one proposed by Raviv and Landskroner (2009), which analogously includes a fixed payment to be paid to bank managers for maintaining solvency supplemented by an options-based form of compensation. Raviv and Landskroner add to these components of their proposed compensation package a third, fixed component that would be payable if the value of the bank's assets at maturity remains between two upper thresholds. Raviv and Landskroner add this additional component to encourage an "interior level of volatility" between the extremes associated with "a long 'cash or nothing' call option... that pays a fixed amount of money at maturity if the value of assets is above some upper threshold and a short position in a similar option with a higher strike price" (Raviv and Landskroner, p. 6). Raviv and Landskroner do not discuss their proposal in the context of the structure of deposit insurance premiums, but their suggested policy is cited within the FDIC's (2010) recent proposal.

\section{Regulation of Bank Management Compensation: An Evaluation}

Does the academic literature in economics and finance support actual and proposed regulation of the structure of bank management compensation? From an empirical standpoint, the answer is ambiguous. There is some evidence that making bank executives' pay more closely attuned to shareholder interests may contribute to greater risk taking as well as increased risk shifting onto bondholders and taxpayers. There is also some evidence against this conclusion, however. Consequently, the available empirical evidence fails to provide strong support for government management-compensation regulation aimed at limiting bank risk-taking behavior.

What guidance does theory offer? At the most basic level, economic theory identifies three potential pitfalls of regulations aimed specifically at restraining bank management compensation. One pitfall is that explicit ceilings that constrain 
executive pay below market clearing levels - which already show signs of adjusting to altered perceptions of risk [see, for instance, Davis (2010)] — are likely to prove to be counterproductive in relation to the overriding objective of producing a safe and sound banking industry. As any first-year economics student learns, establishing a ceiling wage rate beneath the equilibrium level paid to suppliers of labor of a particular skill causes employers to desire to obtain more units of labor at the ceiling wage. Such a policy simultaneously induces a reduction in the quantity of labor supplied at the lower wage rate. The consequence is a shortage in the market for labor possessing the particular skill utilized by the industry in question. In the case of the banking industry, there would be a shortage of labor possessing talents in managing risks.

The second pitfall is the danger of assuming that the effects of bank pay regulation can be evaluated without reference to the rest of the economy. A shortage of executive talent would not result because a number of people possessing risk management skills would not usefully employ them. Instead, a number of these people would opt to provide those skills to other industries, including firms in other financial industries as well as companies in nonfinancial industries seeking financial officers that would be able to offer higher, unregulated wages. Of course, these nonbanking industries would be willing to hire only skilled individuals offering levels of productivity per unit of labor commensurate with the higher rates of compensation they would pay. Thus, a predictable effect of restraining executive compensation in the banking industry to a "below market" level would be the departure of the most productive managers to other industries. Among these executives would be people with the best skills in managing risks. The loss of this talent pool would hardly promote improved risk management capabilities within the banking industry.

The third pitfall is a failure to account for feedback effects of wage 
regulations. The potential for a labor shortage within the management ranks and the impending loss of some of the most talented managers to other industries would give banking firms a strong incentive to engage in regulatory avoidance behaviors. Undoubtedly, some institutions likely would respond to regulations on explicit executive compensation by developing implicit forms of compensation-improved benefit packages and miscellaneous forms of executive "perks"-not covered by laws or regulatory rules. Other banks might respond by leaving the "banking" business and reconstituting themselves as an alternative form of uninsured financial institution not subject to compensation restrictions.

Of course, economic staffs of bank supervisory agencies are well aware of these basic economic pitfalls associated with pay restrictions that might effectively impose ceilings on managers' wages. This recognition is surely the reason that bank regulators are always careful to state that, aside from the statutory restrictions imposed on a few bailout recipients by the Economic Stabilization Act of 2008 (see Table 1), there is no intent to place arbitrary "caps" on bankers' pay. Nevertheless, even rules intended to subtly redistribute the forms of compensation received by bank executives ultimately could under some circumstances have the unintended effect of pushing allowed rates of pay beneath levels consistent with market wage rates for skilled financial managers.

For the sake of argument, however, suppose that regulations of bankers' pay could indeed be constructed in some way that ensures that on average there would only be a redistribution of the aggregate rate of managerial compensation without restraining the overall compensation rate below the equilibrium level. Such a policy outcome probably is the implicit intent of recent guidelines issued by the Federal Reserve and the FDIC's current proposal to condition a bank's deposit insurance premium rate on the bank's managerial compensation structure. Could the FDIC counter moral-hazard-based risk shifting by charging lower premiums to banks 
adopting bonus-shares arrangements_-potentially consistent with a general rule combining bonuses and shares of returns as in Johns et al.-type rule or with a specific multipart compensation package such as the one proposed by Raviv and Landskroner? It is not apparent that the answer to this question is yes. One difficulty is that the Johns et al. deposit-rate-setting rule is derived under several constraining assumptions:

a. The payment owed to insured depositors $(F)$ is fixed. Flannery (1982) and others have provided evidence that retail deposits are quasi-fixed factors of production, suggesting that expenses associated with these deposits are indeed fixed.

Nevertheless, recent expansions in deposit insurance coverage have encompassed many negotiable deposit instruments with variable payments determined on a continuous basis in the money markets. In these deposit markets, one key determinant of these variable payments is the demand for deposits by banks, implying that such payments in fact vary endogenously alongside bank decisionmaking. It is unclear how incorporating endogeneity of payments to depositors would affect a Johns et al.-style compensation-structure-based rule for setting deposit insurance premiums.

b. The bank optimizes only on the asset side of the balance sheet. Since early in the literature on bank behavior dating back to Klein's (1971) analysis [see VanHoose (2010, Chapter 3) for a recent review], it has been understood that the assumption that there is no interdependence of asset and liability decisions-commonly called the assumption of portfolio separation - can generate artificially narrow conclusions about the bank decision-making process. Sealey (1985) showed that three conditions must be met for portfolio separation to hold: (a) shareholder unanimity regarding portfolio decisions, (b) separability of the bank's resource 
cost function, and (c) access by the bank to a market for funds with equal ex post borrowing and lending rates. Many applications of financial theory to the banking firm - including the analysis of John et al.- rely explicitly or implicitly on the assumption of portfolio separation. Nevertheless, at best the empirical evidence regarding its real-world applicability is mixed; see, for instance, Elyasiani et al. (1995). Relaxing the assumption of portfolio separation undoubtedly would greatly alter the specific conclusions obtained by John et al. and certainly would considerably complicate the structure of the optimal compensation arrangement forthcoming from their analysis.

c. Bank equity is fixed. There are two potential problems associated with John et al.'s assumption that equity is exogenous. The first possible difficulty relates to their analysis of the interplay between capital regulation and the setting of deposit insurance premiums. They envision capital regulation as requiring the assumed exogenous level of deposits to be lower relative to equity, which then generates lower asset risk in their model. This interpretation of capital regulation, however, is inconsistent with forms of capital regulation utilized under Basel I and Basel II, in which capital requirements relate the required equity capital to loans and other risk-based assets. Their analysis of joint determination of capital regulation and deposit insurance premiums would be considerably altered if a more realistic capital-regulation setting were contemplated. The second possible problem amounts to a reformulated perspective on point $b$ above. In the event of interdependence between the asset and liability side of the bank's balance sheet - and Basel-style capital regulation forces such interdependence even if the conditions identified by Sealey hold true - then endogeneity involving loans and bank capital would yield a wider set of margins along which a bank must optimize. Whether the analysis of John et 
al. would generalize to an environment with interdependence between bank loans and equity also is unclear.

d. Equity Holders Care Only about the Expected Value of Cash Flows. The John et al. analysis presumes unanimity of equity holders in seeking to maximize the expected value of cash flows. A majority concern among shareholders about the standard deviation of their share of cash flows in John et al.'s framework undoubtedly would result in outcomes more attuned to the interests of risk-averse regulators, even in the presence of deposit insurance, and hence reduced effects of implicit regulation of management pay structure via settings of deposit insurance. Indeed, it is conceivable that extending John et al.'s model to include risk aversion on the part of a sufficient fraction of shareholders could yield diminishing benefits to such regulation as the degree of risk aversion rises.

Thus, potential social benefits of regulations on bank management compensation are likely to be ambiguous even for a subtly crafted effort to alter the distributional structure of pay packages. Even if regulations might succeed in avoiding damaging resource allocation effects while redistributing sources of compensation in ways aimed at preventing undesired risk shifting owing to the moral hazard owing to deposit insurance, the ultimate impacts of such rules remain uncertain. Within sufficiently constrained theoretical frameworks, such regulations potentially could alter risk-shifting incentives in ways that would enhance bank safety and soundness. If real-world elements from which previous academic analyses have abstracted were taken into account, however, it is not apparent that proposed restrictions on bank pay practices would necessarily accomplish this objective. 


\section{Conclusion}

Deposit insurance structured without appropriate consideration of risks magnifies shareholders' incentives to shift risks onto debt holders. In theory, tying management compensation to equity returns could increase the extent to which banks shift risks to bond holders and depositors - and consequently to deposit insurers. These considerations provide motivation for recent actual and proposed government restrictions on bank management compensation.

Nevertheless, the case for regulating bankers' pay is not very strong. Empirical findings to date provide mixed conclusions regarding the relationship between the structure of bank management compensation and risk-taking behavior. Although there has been an increase in the sensitivity of bank managers' pay to performance in recent years, there is very mixed evidence regarding the effect of this development on banks' risk-taking behavior. Furthermore, research suggests that effects of the relative shares of shareholders, debt holders, and managers in bank risk-taking decisions depend considerably on factors such as the magnitude of the moral hazard problem created by deposit insurance and the governance structure in place at banks. These results suggest that a variety of factors that heretofore have not been studied carefully likely influence how greater sensitivity of managers' pay to performance affects bank risk-taking behavior.

Despite the uncertain evidence regarding the relationship between bank management compensation and risk, the U.S. government has subjected the pay of executives at a few banks accepting the most substantial government bailouts to explicit caps. In addition, the government has issued guidelines for management compensation at all other banks accepting assistance. Furthermore, the Federal Reserve has incorporated analysis of management compensation programs into its supervisory examination process (see, for instance, Hopkins, 2010) and under pending legislation could be required to establish explicit standards for evaluating 
such programs. In response, some banks have shifted toward greater emphasis on salary over bonuses in management-compensation package - even though some of the theoretical contributions reviewed above that support the idea of factoring bankers' pay into regulations suggest that certain types of bonus packages can contribute to lower risk. Finally, the Federal Deposit Insurance Corporation has proposed conditioning deposit insurance premiums on the structure of bank management compensation, both to take into account the risk implications of alternative pay plans and to try to influence the pay structures that banks select so as reduce risks.

Even from a purely theoretical standpoint, however, the risk implications of regulatory and supervisory involvement in bank management compensation are debatable. Theoretical research suggests that the effects of performance-based pay on risk depend on a number of factors, such as the relationship between managers' preferences regarding compensation and risk, the strength of wealth effects, and the nature of informational asymmetries faced by shareholders, debt holders, and regulators. Conditioning deposit insurance premiums on a bank's pay structure might alter risk-shifting incentives created by moral hazard arising from deposit insurance. Nevertheless, to date theoretical predictions about the effects of this policy proposal potentially hinge on a number of simplifying assumptions of questionable validity.

Perhaps the most important difficulty, however, is that any restriction likely would push overall compensation levels for bank executives below market levels. Effective ceilings on bankers' pay would push the quantity of executive talent demanded by banks above the quantity supplied, resulting in a shortage of qualified managers. The reduction in the pool of available executive talent if this eventuality were to arise likely would contribute to higher rather than lower risks in the banking industry. 


\section{REFERENCES}

Adler, Joe, 2010a, FDIC board split on exec pay plan, American Banker, January 13.

Adler, Joe, 2010b, FDIC plan to link premiums to compensation already under fire, American Banker, January 8.

Anderson, Christopher, David Becher, and Terry Campbell II, 2004, Bank mergers, the market for bank CEOs, and managerial incentives, Journal of Financial Intermediation 13, 6-27.

Ang, James, Beni Lauterbach, and Ben Schreiber, 2001, Internal monitoring, regulation, and compensation of top executives in banks, International Review of Economics and Finance 10, 325-335.

Barro, Jason, and Robert Barro, 1990, Pay, performance, and turnover of bank CEOs, Journal of Labor Economics 8, 448-481.

Becher, David, Terry Campbell II, and Melissa Frye, 2005, Incentive compensation for bank directors: The impact of deregulation, Journal of Business 78, $1753-1777$.

Bliss, Richard, and Richard Rosen, 2001, CEO compensation and bank mergers, Journal of Financial Economics 61, 107-138.

Bolton, Patrick, Hamid Mehran, and Joel Shapiro, 2010, Executive compensation and risk taking, Columbia University, Federal Reserve Bank of New York, and University of Oxford, May 27.

Chen, Carl, Thomas Steiner, and Ann Marie Whyte, 2006, Does stock option-based executive compensation induce risk-taking? An analysis of the banking industry, Journal of Banking and Finance 30, 915-945.

Chen, Carl, Thomas Steiner, and Ann Marie Whyte, 1998, Risk-taking behavior and management ownership in depository institutions, Journal of Financial Research 21, 1-16. 
Čihák, Martin, Andrea Maichler, Klaus Schaeck, and Stéphanie Stolz, 2009, Who disciplines bank managers? IMF Working Paper WP/09/272, December.

Cooper, Elizabeth Webb, 2009, Monitoring and governance of private banks, Quarterly Review of Economics and Finance 49, 253-264.

Craig, Valentine, 2004, The changing corporate governance environment: Implications for the banking industry, FDIC Banking Review 16, 121-135.

Crawford, Anthony, John Ezzell, and James Miles, 1995, Bank CEO payperformance relations and the effects of deregulation, Journal of Business $68,231-256$.

Crittenden, Michael, 2010, FDIC moves to tie fees to bank pay, Wall Street Journal, January 13.

Davis, Paul, 2010, Seeking new balance on pay policies, American Banker, April 5.

Demirgüç-Kunt, Ash, Edward Kane, and Lue Laeven, 2008, Deposit insurance design and implementation: Policy lessons from research and practice, in Demirgüç-Kunt, Ash, Edward Kane, and Lue Laeven (eds.), Deposit Insurance around the World, Cambridge: MIT Press: pp. 3-26.

Elyasiani, Elyas, Kenneth Kopecky, and David VanHoose, 1995, Costs of adjustment, portfolio separation, and the dynamic behavior of bank loans and deposits, Journal of Money, Credit, and Banking 27, 955-974.

Federal Deposit Insurance Corporation, 2010, Incorporating employee compensation criteria into the risk assessment system, Advance Notice of Proposed Rulemaking, 12 CFR Part 327, January 12.

Flannery, Mark, 1982, Retail bank deposits as quasi-fixed factors of production, American Economic Review 72, 527-536.

Grant, C. Terry, and Gerry Grant, 2008, Can regulations curb excessive executive pay? Strategic Finance, September, 31-39. 
Grocer, Stephen, 2010, Banks set for record pay, Wall Street Journal, January 16.

Gropp, Reint, and Matthias Köhler, 2010, Bank owners or bank managers: Who is keen on risk? Evidence from the financial crisis, Center for European Economic Research Discussion Paper No. 10-013, February.

Hagendorff, Jens and Vallascas, Francesco, 2010, CEO Pay Incentives and RiskTaking: Evidence from Bank Acquisitions (March 31). Available at SSRN: http://ssrn.com/abstract=1625689.

Harjoto, Maretno, and Donald Mullineaux, 2003, CEO compensation and the transformation of banking, Journal of Financial Research 26, 341-354.

Hill, Jennifer, 2009, New trends in the regulation of executive remuneration, Working Paper, Vanderbilt Law School.

Hopkins, Cheyenne, 2010, Fed finds flaws in big banks' pay packages, American Banker, June 22.

Houston, Joel, and Christopher James, 1995, CEO compensation and bank risk: Is compensation in banking structured to promote risk taking? Journal of Monetary Economics 36, 405-431.

Hubbard, R. Glenn, and Darius Palia, 1995, Executive pay and performance: Evidence from the U.S. banking industry, Journal of Financial Economics 39, 105-130.

John, Kose, Hamid Mehran, and Yiming Qian, 2010, Outside monitoring and CEO compensation in the banking industry, Journal of Corporate Finance 16, 383-399.

John, Kose, and Yiming Qian, 2003, Incentive features in CEO compensation in the banking industry, Federal Reserve Bank of New York Economic Policy Review, April, 109-121.

John, Kose, Anthony Saunders, and Lemma Senbet, 2000, A theory of bank regulation and management compensation, Review of Financial Studies 13, 
95-125.

John, Kose, Anthony Saunders, and Lemma Senbet, 1995, Perspectives on bank capital regulation and managerial compensation, Journal of Banking and Finance 19, 735-737.

Kay, Ira, and Steven Van Putten, 2007, Myths and Realities of Executive Pay, Cambridge: Cambridge University Press.

Klein, Michael, 1971, A theory of the banking firm, Journal of Money, Credit, and Banking 3, 205-218.

Laeven, Luc, and Ross Levine, 2009, Bank governance, regulation, and risk taking, Journal of Financial Economics 93, 259-275.

Macey, Jonathan, and Maureen O'Hara, 2003, The corporate governance of banks, Federal Reserve Bank of New York Economic Policy Review 16, 91-107.

Mason, David, 2009, Why government control of bank salaries will hurt, not help, the economy, Backgrounder, Heritage Foundation, No. 2336, November 4.

Minnick, Kristina, Haluk Unal, and Liu Yang, 2009, Pay for performance? CEO compensation and acquirer returns in BHCs, FDIC Center for Financial Research Working Paper No. 2009-03, December.

Palia, Darius, and Robert Porter, 2004, The impact of capital requirements and managerial compensation on bank charter value, Review of Quantitative Finance and Accounting 23, 191-206.

Raviv, Alon, and Yoram Landskroner, 2009, The 2007-2009 financial crisis and executive compensation: Analysis and a proposal for a novel structure, Working Paper, New York University, June 15.

Ross, Stephen, 2004, Compensation, incentives, and the duality of risk aversion and riskiness, Journal of Finance 59, 207-225.

Saunders, Anthony, Elizabeth Strock and Nickolaos G. Travlos (1990), Ownership 
Structure, Deregulation, and Bank Risk Taking, Journal of Finance 45, 2, 643-654.

Schreiber, Ben, 1997, The owner-manager conflict in insured banks: Predetermined salary versus bonus payments, Journal of Financial Services Research 12, 303-326.

Sealey, C.W., Jr., 1985, Portfolio separation for stockholder-owned depository financial intermediaries, Journal of Banking and Finance 9, 477-490.

Sierra, Gregory, Eli Talmor, and James Wallace, 2006, An examination of multiple governance forces within bank holding companies, Journal of Financial Services Research 29, 105-123.

VanHoose, David, 2010, The Industrial Organization of Banking: Bank Behavior, Market Structure, and Regulation, Heidelberg: Springer.

Webb, Elizabeth, 2008, Regulator scrutiny and bank CEO incentives, Journal of Financial Services Research 33, 5-20.

Westman, Hanna, 2010, The role of ownership structure and regulatory environment in bank corporate governance, Working Paper, Hanken School of Economics.

Williams, Melissa, Timothy Michael, and Ramesh Rao, 2008, Bank mergers, equity risk incentives, and CEO stock options, Managerial Finance 34, 316-327. 